\title{
Motivations and Attitudes of Men Towards Sperm Donation: Whom to Donate and Why?
}

\author{
João Areias ${ }^{1}\left[\right.$ ] Jorge Gato ${ }^{1} \cdot$ Mariana Moura-Ramos $^{2}$
}

Accepted: 21 December 2020 / Published online: 27 January 2021

(c) The Author(s), under exclusive licence to Springer Science+Business Media, LLC part of Springer Nature 2021

\begin{abstract}
Background The widespread access to medically assisted reproduction (MAR) techniques for all women, regardless of any infertility diagnosis, has led to an increased, but as yet unmet, demand for sperm donors in Portugal. For this study, we deployed an online survey to explore men's motivations for donating and their attitudes toward anonymity and donating for specific groups.

Method The study's sample comprised men who were eligible to donate sperm $(\mathrm{N}=282)$. The relationships between these factors and participants'psychological and sociodemographic characteristics were also explored.

Results The results mostly indicated altruistic reasons for donating, positive attitudes toward anonymity, and a greater willingness to donate to infertile women. Overall, sexual orientation was not associated with the participants' attitudes and motivations. Age, education level, conscientiousness, empathic concern, and conservative and religious values were associated with the participants' motivations and attitudes toward sperm donation.

Conclusion Recruitment campaigns should therefore consider the specific motivations, attitudes, and psychosocial characteristics of potential sperm donors. Indeed, parenthood is a universal right, so sperm donation should be encouraged, regardless of recipients' fertility status. Clear information about the identifiability of sperm donors should also be provided.
\end{abstract}

Keywords Motivations $\cdot$ Attitudes $\cdot$ Sperm donation $\cdot$ Sexual orientation

\section{Introduction}

Gamete donation is the only means of achieving parenthood for those unable to conceive a child with their own gametes. In Portugal, about 9\% of couples of reproductive ages are unable to have children due to infertility, and a minority of those will seek to undergo medically assisted reproduction (MAR) with donated gametes or embryos to achieve parenthood (Zegers-Hochschild et al., 2017). Lesbian couples and single women also need to undergo MAR to achieve motherhood, whether through intrauterine

João Areias

areias.jcarlos@gmail.com

1 Faculty of Psychology and Education Sciences, University of Porto (FPCEUP), Porto, Portugal

2 Reproductive Medicine Unit, Clinical Psychology Unit, Center for Research in Neuropsychology and Cognitive and Behavioral Intervention, Centro Hospitalar E Universitário de Coimbra, University of Coimbra, Coimbra, Portugal insemination or in vitro fertilization with donated sperm. While the medical procedures are technically identical to performing autologous MAR, the use of donated gametes or embryos brings additional concerns and difficulties. In recent years, issues have arisen about identifying donors, whether through legislation or the use of direct-to-consumer DNA testing, and this has raised important concerns (Pennings, 2019a, b). The topic has received more attention in Portugal, where legislation about the identifiability of donors has been recently changed.

\section{Anonymity in Gamete Donation or Lack of It}

In 2016, Portuguese law extended MAR treatment to all women, regardless of their marital status, sexual orientation, or any infertility diagnosis. Consequently, it is expected that there will be an increase in the number of children born as a result of heterologous MAR, particularly using donated sperm, in the coming years. There is controversy, however, about who should be able to resort to MAR, as well as a moral dilemma about the identifiability of sperm donors and 
compensation for the donation (Almeling, 2006; Fortescue, 2003).

An understanding that donor-conceived people have the right to learn the identity of their donors led to legislative changes in some countries to remove donor anonymity (Golombok, 2015). In 1985, Sweden became the first country to allow children conceived through MAR to learn their genetic origins once they reach an age of sufficient maturity (Ekerhovd, Faurskov, \& Werner, 2008). Since then, several countries-such as the Netherlands, Finland, the UK, and more recently Portugal-have also changed their laws to allow donor-conceived children to learn the identity of the donors.

Indeed, in 2018, the Portuguese Constitutional Court imposed changes in the anonymity regime for all treatments involving third-party reproduction, such as donated sperm, oocytes, and embryos (Acórdão n ${ }^{\circ}$ 225/2018). Following this, a child conceived using donated sperm, oocytes, or embryo was allowed to learn the donor's identity on reaching the age of 18 years old. In line with this change, the importation of gametes was limited to countries with nonanonymous donation. A transition period was established for situations where gametes were donated before the legislative change, and for the following 3 years, the identities of donors would remain anonymous.

The issue of donor identifiability has arisen from a social debate about weighing the rights and duties of the resulting child against the rights of the donor. On the one hand, it is argued that the child has the right to know his or her genetic origins, ancestry, and history (Ravitsky, 2017), while on the other hand, it is argued that the donor has the right to privacy and distance from the child (Pennings, 2019a, b). Of course, these conflicting rights have led to heated debate (Pennings, 2019a, 2019b; MacPherson, 2019).

Since sperm donation is considered an altruistic act (Almeling, 2006; Ekerhovd et al., 2008; Fortescue, 2003; Hedrih \& Hedrih, 2012; Thijssen, Provoost, Vandormael, Dhont, Pennings, \& Ombelet, 2017; Van der Broeck, Vandermeeren, Vanderschueren, Enzlin, Demyttenaere, \& D'Hooghe, 2013), the lack of anonymity may deter donors and increase the gap between supply and demand. In relation to MAR, another ethical debate exists about recruiting sperm bank donors through financial compensation. In Portugal, each donation is rewarded with around $€ 40$, with the donor being exempt from paying any user taxes in the National Health Service. However, not all public systems reward gamete donation. In France, for example, donation is anonymous and free, and the donor must already be a parent (Kalampalikis, Fieulaine, Doumergue, \& Deschamps, 2013).

A study of sperm donation in Portugal is thus necessary and relevant for a number of reasons. First, access to MAR has been widened to all women, regardless of their marital status and sexual orientation. Second, the recent end to anonymity may influence the motivation to donate. Finally, there is a shortage of gametes. Our goal in this work is therefore to examine the motivations and attitudes toward sperm donation in Portugal, as well as identify which characteristics of potential donors are associated with these processes.

\section{Motivations and Attitudes Toward Sperm Donation}

Three major motivations to donate sperm have been highlighted in the literature: (i) altruism, (ii) financial compensation, and (iii) verification of one's own fertility (Ekerhovd et al., 2008; Hedrih \& Hedrih, 2012). Altruism refers to a willingness to help others without prospect of personal benefit. In the case of sperm donation, this relates to a desire to help childless couples to fulfil their dream of having a child (Ekerhovd et al., 2008; Hedrih \& Hedrih, 2012; Thijssen et al., 2017; Van der Broeck et al., 2013). Altruism has been associated with financial compensation becoming less important, with many donors saying they would still donate if no compensation were provided (Ekerhovd et al., 2008; Hedrih \& Hedrih, 2012; Thijssen et al., 2017). However, other studies have found that many potential donors would cease donating if compensation was discontinued (Van der Broeck et al., 2013). Financial compensation is therefore another motivation for donating sperm (Bay et al., 2014; Hedrih \& Hedrih, 2012; Thijssen et al., 2017; Van der Broeck et al., 2013). A third motivation relates to verifying the donor's own fertility (Hedrih \& Hedrih, 2012; Thijssen et al., 2017; Van der Broeck et al., 2013). Studies have shown that some individuals show a curiosity and willingness to pass on their "good genes," as well as a need to confirm their capacity to procreate (Thijssen et al., 2017), although the latter phenomenon was only observed among young people (Thijssen et al., 2017). One of our goals in this study was to explore possible differences in these three motivations among our participants.

Different attitudes toward sperm donation have been identified, such as attitudes toward the potential receivers of the donation, the relationship with the resulting offspring, the anonymity of the donation, and the process's social aspects (Hedrih \& Hedrih, 2012; Thijssen et al., 2017). In this study, we discuss attitudes toward anonymity and attitudes toward donating to lesbian couples versus other family configurations.

As stated above, the debate about donor anonymity extends across many countries beyond Portugal. A study in Belgium investigated the motivations and attitudes of candidate sperm donors (Thijssen et al., 2017). Half of these participants said they would like to know how many children were conceived from their sperm, but only a quarter wanted to receive information about the family and any children who were conceived. Most participants expressed 
that parents should decide whether to inform children about their genetic origin, but half of them believed that parents should be honest with their children. Most indicated their willingness to provide information about themselves to resulting children, but only $26 \%$ of them were willing to donate if their identity might be disclosed. Another study among Danish donors aimed to examine the motivations and attitudes toward sperm donation (Bay et al., 2014). Half of the participants stated they would no longer donate if anonymity could not be assured, and only a minority said they would, or might, continue donating. Most donors said they would reveal non-identifying information about themselves, would like to know how many children were conceived from their sperm, and would accept that the children could learn their identity. These studies show a relatively positive view of non-anonymous donation, even though men tend to withdraw from donating if their identities may be disclosed. We would therefore expect a similar pattern of attitudes toward non-anonymity in Portugal.

Another controversial topic with assisted reproduction with donated gametes relates to the recipients. Overall, positive attitudes toward donation to single women and/ or lesbian couples have been reported (Bay et al., 2014; Ekerhovd et al., 2008; Thijssen et al., 2017), but negative attitudes toward lesbian and gay parenting families continue to be reported (e.g., Crawford \& Solliday, 1996; Gato \& Fontaine, 2013, 2016). College students in the USA, for example, considered gay couples to be less emotionally suited and less apt to become parents when compared with heterosexual couples (Crawford \& Solliday, 1996). In Portugal, Gato and Fontaine (2013) highlighted university students' apprehension toward adoption by same-sex couples when it comes to the normative sexual and gender development of children. This apprehension was especially strong in cases where a boy is adopted by a lesbian couple, compared to when a girl is adopted by a gay couple (Gato \& Fontaine, 2013). The same authors (2016) later confirmed that among a sample of undergraduate students from helping professions, men expressed more negative attitudes toward same-sex families than women did. The participants also considered that the sexual orientation of the couple only impacted psychosexual development in cases where a boy is adopted by two men. When evaluating parental competences, male participants believed that lesbian and gay couples were less stable and less suited to become parents, as well as more likely to harm the child, when compared with heterosexual couples (Gato \& Fontaine, 2016, 2017). Concerning the impact of the potential donors' sexual orientation, Freeman et al. (2016) showed that gay and bisexual men had an open mind when it came to anonymity, and they were more willing than heterosexual men to be contacted by any conceived children.

\section{Correlates of Motivations and Attitudes Toward Sperm Donation}

Numerous factors can influence the motivations and attitudes of individuals toward sperm donation. In this study, besides the sexual orientations of donors and recipients, we investigated the role of other characteristics of potential donors-such as personality traits (White, Poulsen, \& Hyde, 2017), empathy (Verhaert \& Van den Poel, 2011), social values (Ryckman, Gold, Reubsaet, \& van den Borne, 2009), and religious values (Rubio, 2015) —in influencing motivations and attitudes toward sperm donation.

\section{Personality Traits}

Conscientiousness is described as a tendency for people to be hardworking, purposeful, and disciplined, as opposed to being easygoing, unambitious, and weak-willed (McCrae \& Costa, 2008). It has also been identified as particularly relevant to altruistic behaviors. For instance, highly conscientious people have a greater tendency to volunteer their time (White et al., 2017). Furthermore, one study that aimed to explore the relationship between motivation for post-mortem body part donation and personality traits (Bolt, Eisinga, Venbrux, Kuks, \& Gerrits, 2011) highlighted conscientiousness as a major motivation for body part donation.

Openness to experience describes imaginative, curious, and exploratory tendencies rather than rigid, practical, and traditional tendencies (McCrae \& Costa, 2008). People with a high level of openness are not passive recipients of a panoply of experiences they are unable to projectinstead, they actively seek new experiences. However, closed individuals tend to be traditional and repetitive, and they oblige their functions to escape from stress (McCrae \& Costa, 1997). We therefore intended to explore the relationship between conscientiousness and openness to experience and the attitudes and motivations toward donating sperm.

\section{Empathy}

Decety and Jackson (2004) defined empathy as a sense of similarity between the feelings of the self and the feelings of others. It has been established that empathy is an antecedent to various altruistic behaviors (Batson, 1987). Empathy can also influence the perceived benefits of deciding to donate organs, and this affects how motivated individuals are to donate for themselves or for others (Cohen \& Hoffner, 2013). People with high levels of empathic concern make donations in various contexts, with them focusing on alleviating the 
suffering of others and seeming rather other-oriented and compassionate toward others (Verhaert \& Van den Poel, 2011). Given this, we therefore intend to explore the relationship between empathic concern and the motivations and attitudes toward sperm donation.

\section{Values}

Schwartz (1992) defined values as criteria that individuals use to select and justify their actions, as well as the basis for evaluating events and people (including the self). This theory proposed an organization of 10 types of motivational values, namely power, achievement, hedonism, stimulation, selfdirection, universalism, benevolence, tradition, conformity, and security (Schwartz, 1992).

The study of Ryckman et al. (2009) aimed to identify which personal values were associated with intentions to register as an organ donor. It found that individuals with higher levels of social conformity, but lower levels of hedonism expressed a greater intent to register as organ donors. The study also highlighted how personal values could play an important role in health-education campaigns that seek to increase the supply of donor organs for transplantation.

Conservative (or Conservation in Schwartz's terminology) values express a desire to preserve the status quo (e.g., family security, social order) and the security it provides in relationships with others, traditions, and institutions (Schwartz, 1992, 1994). Hence, we therefore sought to explore the relationship between conservative values and the motivations and attitudes toward sperm donation.

\section{Religious Values}

Although the Catholic Church has influenced Portuguese society for a long time, nowadays, "Portugal is, in a modern way, simultaneously a secularized, religious and Catholic country" (Dix, 2010, p. 25). Catholicism tends to reject alternative family formation, arguing about the nature of sex, marriage, and the family, as well as the dignity of the embryo, the rights of the child, and the means used to improve biological reproduction (Rubio, 2015). Thus, we aimed to explore the relationship between religious values and the motivations and attitudes toward sperm donation.

\section{Study Aims}

In summary, the goals of this study were as follows:

1. To explore possible differences between the motivations to donate, attitudes toward anonymity, and attitudes toward donating for specific groups

2. To explore possible differences between these motivations and attitudes as a function of sexual orientation
3. To explore the relationship between the motivations to donate, attitudes toward anonymity, attitudes toward donating for specific groups, and participants' psychological characteristics

Regarding our second goal, we expected heterosexual participants to show more negative attitudes toward donating to lesbian couples and/or single lesbian women when compared to heterosexual couples and/or single heterosexual women (Hypothesis 1). No differences were anticipated in the case of gay and bisexual men (Hypothesis 2). Furthermore, we expected heterosexual participants to show more negative attitudes toward non-anonymous donation than non-heterosexual participants (Hypothesis 3).

\section{Method}

\section{Participants}

Our sample comprised 282 male participants aged between 18 and 40 years. As shown in Table 1, most participants were heterosexual, lived in the north of Portugal, had (or were studying for) a higher education degree (generally in the social sciences), were employed, had a monthly income not exceeding $€ 1000$, were single, did not have children, and had never donated sperm before. In terms of political orientation, most participants showed a centrist tendency.

\section{Procedure}

Data were collected through an online questionnaire that was distributed through social media networks, namely Facebook and Instagram, between December 2019 and March 2020. The inclusion criteria for the study were eligibility to donate sperm and an age between 18 and 40 years. Furthermore, a Facebook page was created for the study, such that participants could read about the aims of the research and find a hyperlink to the questionnaire. The study was also advertised among LGBT associations, since a goal of the investigation was to explore how the sexual orientation of the participants could influence their motivations to donate sperm. In addition, 100 printed questionnaires in sealed envelopes were also personally distributed among the social contacts of research team members. Of these, only 17 were completed and returned, but this low return rate can be attributed to the COVID-19 pandemic and the resulting lockdown measures implemented by the Portuguese government on March 18, 2020, because these prevented social exchanges between researchers and potential participants.

Both versions of the questionnaire (i.e., paper and online) included an informed consent form, so participants could 
Table 1 Sociodemographic variables

\begin{tabular}{|c|c|c|}
\hline & $M$ & $S D$ \\
\hline Age* & 26.68 & 6.81 \\
\hline Education level & 4.82 & 0.89 \\
\hline Political orientation** & 5.81 & 2.43 \\
\hline \multirow[t]{2}{*}{ Monthly income $e^{* * *}$} & 2.27 & 1.26 \\
\hline & $n$ & $\%$ \\
\hline \multicolumn{3}{|l|}{ Sexual orientation } \\
\hline Heterosexual & 192 & 68.10 \\
\hline Bisexual & 27 & 9.60 \\
\hline Gay & 59 & 20.90 \\
\hline Asexual & 2 & 0.70 \\
\hline Other & 2 & 0.70 \\
\hline \multicolumn{3}{|l|}{ "Race"/ethnicity } \\
\hline White/Caucasian & 263 & 93.26 \\
\hline Other & 19 & 6.74 \\
\hline \multicolumn{3}{|l|}{ Region of residence } \\
\hline North & 92 & 32.60 \\
\hline South & 14 & 5.00 \\
\hline Center & 42 & 14.90 \\
\hline Greater Porto & 55 & 19.50 \\
\hline Greater Lisbon & 63 & 22.30 \\
\hline Madeira & 5 & 1.80 \\
\hline Azores & 5 & 1.80 \\
\hline Other & 6 & 2.10 \\
\hline \multicolumn{3}{|l|}{ Place of residence } \\
\hline Major city & 121 & 42.90 \\
\hline Small city, town, or rural area & 161 & 57.10 \\
\hline \multicolumn{3}{|l|}{ Marital status } \\
\hline Married/civil union & 68 & 24.10 \\
\hline Single/separated/divorced & 214 & 75.90 \\
\hline \multicolumn{3}{|l|}{ Professional status } \\
\hline Employed & 163 & 57.80 \\
\hline Unemployed/students & 119 & 42.20 \\
\hline \multicolumn{3}{|l|}{ Type of contract***** } \\
\hline Temporary & 41 & 25.30 \\
\hline Permanent & 98 & 60.50 \\
\hline N/A & 23 & 14.20 \\
\hline \multicolumn{3}{|l|}{ Area of study***** } \\
\hline Agricultural Sciences & 5 & 3.20 \\
\hline Engineering and Technology & 23 & 14.60 \\
\hline Humanities and Arts & 21 & 13.30 \\
\hline Medical and Health Sciences & 27 & 17.10 \\
\hline Natural Sciences & 14 & 8.90 \\
\hline Social Sciences & 67 & 42.40 \\
\hline Other & 1 & 0.50 \\
\hline \multicolumn{3}{|l|}{ Parental status } \\
\hline Yes & 33 & 11.70 \\
\hline No & 249 & 88.30 \\
\hline \multicolumn{3}{|l|}{ Have you ever donated sperm? } \\
\hline Yes & 6 & 2.10 \\
\hline No & 276 & 97.90 \\
\hline
\end{tabular}

*Valid $n=280$

$* *$ Valid $n=281$
Table 1 (continued)

$$
\begin{aligned}
& * * * \text { Valid } n=271 \\
& * * * * \text { Valid } n=162 \\
& * * * * * \text { Valid } n=158
\end{aligned}
$$

read about the goals of the study and be aware of their right to confidentiality and anonymity before checking boxes to indicate consent at the start of the questionnaire. Contact details for the principal researcher were also provided, so participants could reach out with any questions or concerns. Participants could withdraw from the questionnaire at any point without consequences. Completing the questionnaire took no longer than $20 \mathrm{~min}$, and participation brought no direct benefits to the participants. This study was approved by the Research Ethics Committee of the host institution on November 5, 2019.

\section{Measures}

\section{Sociodemographic Data}

The participants completed a sociodemographic questionnaire, which included questions about age, gender (male or other), sexual orientation (heterosexual, bisexual, gay, or other), "race" and/or ethnicity (open question), region of residence (North, South, Center, Greater Porto, Greater Lisbon, Madeira, Azores), place of residence (major city, small city, town, or rural area), education level (4th grade, 6th grade, 9th grade, 12th grade, graduate, masters, or doctorate) and area of study (whenever applicable), political orientation (from $0=$ left wing to $10=$ right wing), marital status (married/nonmarital partnership, single, separated, divorced, or widower), parental status (having children or not), professional status (full-time job, part-time job, unemployed, or student), job (whenever applicable), and type of contract (temporary, permanent, not applicable), monthly income (up to €500, between $€ 501$ and $€ 1000$, between $€ 1001$ and $€ 1500$, between $€ 1501$ and $€ 2000$, between $€ 2001$ and $€ 2500$, or above $€ 2501$ ), and whether they had ever donated sperm (yes or no).

\section{Motivations to Donate, Attitudes toward Anonymity, and Attitudes toward Donating for Specific Groups}

To measure the motivations to donate, attitudes toward anonymity, and feelings toward donating for specific groups, we adapted the scale of Thorn et al. (2008) to Portuguese language. This scale was divided into three groups of questions: motivation to donate (three items, such as "Financial compensation"), using a Likert scale ranging from 1 (Unimportant) to 6 (Very Important); 
attitudes toward anonymity (three items, such as "Parents should disclose DI conception to the child"), using a Likert scale ranging from 1 (Totally Disagree) to 6 (Totally Agree); and feelings toward donating for specific groups (six items, such as "Lesbian woman without fertility issues"), using a Likert scale ranging from 1 (Not Willing) to 6 (Very Willing). The items were averaged, with higher scores indicating greater importance/agreement/willingness. For each subscale, the items were treated individually, as in the original study of Thorn et al. (2008).

\section{Personality Traits}

We used the Portuguese version of the NEO-FFI (Magalhães et al., 2014), which is a brief version of the NEO-PI-R scale (Costa \& McCrae, 1992). Given our research goals, we selected the Conscientiousness (12 items, such as "I try to perform all the tasks assigned to me conscientiously") and Openness to Experience (12 items, such as "I don't like to waste my time daydreaming") subscales. A five-point Likert scale ranging from 1 (Totally Disagree) to 5 (Totally Agree) was used. The items were averaged, with higher scores indicating greater levels for the measured dimension. The internal consistency values (Cronbach's alphas) presented acceptable values for Openness to Experience $(\alpha=0.62)$ and good values for Consciousness $(\alpha=0.76)$.

\section{Empathy}

To measure empathy, we used the Portuguese version of the Interpersonal Reactivity Index (Davis, 1983; Limpo, Alves, $\&$ Castro, 2010). Considering our research goals, we chose to use only the Empathic Concern subscale (six items, such as "Sometimes I don't feel very sorry for other people when they are having problems"). A five-point Likert scale ranging from 0 (Does not describe me) to 4 (Describes me very well) was used to measure each item. The items were again averaged, with higher scores indicating greater levels of empathic concern. The subscale presented a good internal consistency value $(\alpha=0.75)$.

\section{Social Values}

Social values were measured using the Portuguese version of Schwartz's Values Scale (Schwartz, 1992; Granjo \& Peixoto, 2013). In this study, only the Conservation values were included (six items, such as "He believes that people should do what they're told. He thinks people should follow rules at all times, even when no one is watching"). These were divided into three categories-namely Tradition, Conformity, and Security-with two items in each category. In the present study, the overall subscale of Conservation values was used. Each item was measured using a Likert scale ranging from 1 (Not like me at all) to 6 (Very much like me). The items were averaged, with higher scores indicating greater levels of conservative values. The subscale presented a good internal consistency value $(\alpha=0.74)$.

\section{Religious Values}

Religious values were measured using the item "How important do you consider religious values to be in your daily life?" (Gato, Leal, Coimbra, \& Tasker, 2020). This item was measured using a Likert scale ranging from 1 (Not important at all) to 6 (Extremely important).

\section{Data Analysis Procedure}

To calculate the adequacy of our sample size, the G*Power Software (version 3.1.9.7) was used (Faul, Erdfelder, Lang, $\&$ Buchner, 2007). A power analysis with an alpha $=0.05$ and power $=0.95$ revealed that the projected minimum sample size needed to detect an effect size of $f=0.15$ was $n=129$ (for a repeated measures analysis of variance).

All statistical procedures were conducted using SPSS 26. Repeated measures analyses of variance (RM ANOVAs) were run in order to assess within-subject differences in motivations to donate, attitudes toward anonymity, and attitudes toward donating for specific groups. For each significant result, the Bonferroni post hoc test was applied to explore where any differences specifically exist. Given the unbalanced number of participants in each group, Mann-Whitney tests were performed to assess any differences in (i) motivations to donate, (ii) attitudes toward anonymity, and (iii) attitudes toward donating for specific groups as a function of sexual orientation. (Gay and bisexual men were collected into one group and heterosexual men into another, while two asexual men and two men who described their sexual orientation as "other" were excluded from the analyses.)

In order to examine the association between (i) motivations to donate, attitudes toward anonymity, and attitudes toward donating for specific groups; (ii) sociodemographic characteristics; and (iii) psychological characteristics (i.e., Conscientiousness, Openness to Experience, Empathic Concern, Conservation Values, and Religious Values) and Pearson's r correlation were performed.

\section{Results}

First, we analyzed the distribution of the continuous variables used in the study. All values were within the normality range for both skewness (-2.09 to 0.95$)$ and 
kurtosis (- 1.47 to 4.14) (Kline, 2011). Next, we will report results about (i) within-subject differences in motivations to donate, attitudes toward anonymity, and attitudes toward donating for specific groups; (ii) differences in motivations to donate, attitudes toward anonymity, and attitudes toward donating for specific groups as a function of participants' sexual orientation; and (iii) relationships between motivations to donate, attitudes toward anonymity, and attitudes toward donating for specific groups with participants' sociodemographic and psychological characteristics.

\section{Differences in Motivations to Donate, Attitudes toward Anonymity, and Attitudes toward Donating for Specific Groups}

Within-subject differences were assessed for motivations to donate, attitudes toward anonymity, and attitudes toward donating for specific groups. As can be seen in Table 2, the motivations to donate primarily related to altruistic reasons, because helping someone to have a child differed significantly from both wanting to know one's fertility and gaining financial compensation (difference with a medium-large effect size: $p<0.001, \eta p^{2}=0.12$ ). As for attitudes toward anonymity, a willingness to be contacted by any children when they reach 18 years of age was the least indicated attitude, which differed significantly from the other two options, which were endorsed to a greater extent (difference with a medium effect size: $p<0.001$, $\eta p^{2}=0.09$ ).
Regarding attitudes toward donating for specific groups, heterosexual women with fertility problems represented the group that was most associated with positive attitudes, more so than for lesbian couples, heterosexual women without fertility problems, and lesbian women with fertility problems. Attitudes toward donating to a lesbian woman without fertility problems differed from those toward donating to a heterosexual couple, a heterosexual woman with fertility problems, or a lesbian woman with fertility problems. In turn, attitudes toward donating to a different-sex couple differed from those toward donating to a heterosexual woman with fertility problems or a heterosexual woman without fertility problems. In addition, attitudes toward donating to a heterosexual woman without fertility problems differed from those toward donating to a lesbian woman with fertility problems. In summary, participants held more positive attitudes toward donating to groups with fertility problems (difference with a medium effect size: $p<0.001, \eta p^{2}=0.08$ ).

\section{Differences in Motivations to Donate, Attitudes Toward Anonymity, and Attitudes toward Donating for Specific Groups as a Function of Sexual Orientation}

Differences as a function of sexual orientation were only found for the motivation "Knowing one's fertility," with heterosexual men $(M=4.22 ; S D=1.79)$ assigning more importance to this motivation than non-heterosexual men $(M=3.63 ; S D=1.80)(U=6701.00 ; p=0.010)$. The remaining nonsignificant results are available upon request.

Table 2 Differences in motivations to donate, attitudes toward anonymity and attitudes toward donating for specific groups

\begin{tabular}{|c|c|c|c|c|}
\hline Motivations to donate & $M(S E)$ & $F(2,562)$ & $p$ & $\eta p^{2}$ \\
\hline Financial compensation & $3.75 b(0.10)$ & 36.98 & $<0.001$ & 0.12 \\
\hline Knowing one's fertility & $4.03 b(0.11)$ & & & \\
\hline Helping someone to have a child & $4.85 \mathrm{a}(0.08)$ & & & \\
\hline Attitudes toward anonymity & $M(S E)$ & $F(2,562)$ & $p$ & $\eta^{2}$ \\
\hline Parents should disclose DI conception with the child & $4.24 \mathrm{a}(0.10)$ & 29.26 & $<0.001$ & 0.09 \\
\hline $\begin{array}{l}\text { The institution where DI was performed can provide information about me to the child, } \\
\text { since that information does not identify me }\end{array}$ & $3.95 \mathrm{a}(0.11)$ & & & \\
\hline I would be willing to be contacted by the child when they reached majority ( 18 years old) & $3.30 \mathrm{~b}(0.12)$ & & & \\
\hline Attitudes towards donating for specific groups & $M(S E)$ & $F(3.46,973.22)$ & $p$ & $\eta^{2}$ \\
\hline Lesbian woman without fertility problems & $4.80 \mathrm{c}(0.10)$ & 23.14 & $<0.001$ & 0.08 \\
\hline Different-sex couple & $5.06 \mathrm{~b}(0.09)$ & & & \\
\hline Heterosexual woman with fertility problems & $5.33 \mathrm{a}(0.07)$ & & & \\
\hline Lesbian couple & $4.89 \mathrm{~b}, \mathrm{c}(0.10)$ & & & \\
\hline Heterosexual woman without fertility problems & $4.67 \mathrm{c}(0.11)$ & & & \\
\hline Lesbian woman with fertility problems & $4.97 \mathrm{a}, \mathrm{b}, \mathrm{c}(0.10)$ & & & \\
\hline Lesbian woman without fertility problems & $4.80 \mathrm{c}(0.10)$ & & & \\
\hline
\end{tabular}

Marginal means are reported and values in parentheses represent standard errors. Significant mean differences using the Bonferroni correction for multiple comparisons are denoted by different letters 


\section{Associations Between Motivations to Donate, Attitudes Toward Anonymity, and Attitudes Toward Donating for Specific Groups and Participants' Sociodemographic and Psychological Characteristics}

Regarding sociodemographic characteristics, age negatively correlated with a desire to "know one's fertility" and the belief that "parents should disclose DI conception to the child." Education level also negatively correlated with the desire to "know one's fertility," while the monthly income of participants was negatively correlated with being motivated by financial compensation (Table 3 ).

As shown in Table 3, Conscientiousness positively correlated with wanting to know one's fertility. Empathic Concern positively correlated with helping someone to have a child and positive attitudes toward donating to most groups (i.e., lesbian woman without fertility problems, different-sex couple, lesbian couple, heterosexual woman without fertility problems, and lesbian woman with fertility problems). Conservative values positively correlated with being motivated by financial compensation and wanting to know one's fertility. Finally, religious values negatively correlated with helping someone to have a child and attitudes toward donating to all groups.

\section{Discussion}

The main goal of this study was to highlight what drives men to donate sperm, their attitudes toward anonymity, and their attitudes toward donating for specific groups, as well as to investigate how sexual orientation, psychological traits, and sociodemographic characteristics influence these motivations and attitudes. For reasons of clarity, the results will be discussed in terms of (i) motivations to donate, (ii) attitudes toward anonymity, and (iii) attitudes toward donating for specific groups.

\section{Motivations to Donate}

Consistent with the literature, altruistic motivation seems to be the most significant motivation for donating sperm, emphasizing a desire to help childless couples have children (Ekerhovd et al., 2008; Hedrih \& Hedrih, 2012; Thijssen et al., 2017; Van der Broeck et al., 2013) and diminishing the role of financial compensation in return for donation (Ekerhovd et al., 2008; Hedrih \& Hedrih, 2012; Thijssen et al., 2017). Motivations to donate were generally not associated with the participants' sexual orientation, except for the motivation of "knowing one's fertility," with heterosexual men assigning more importance to this than other men. Non-heterosexual men's lack of interest in their fertility status may be because they generally show a weaker intent to parent children and anticipate stigma upon achieving parenthood (Gato, Leal, Coimbra, \& Tasker, 2020). Furthermore, many non-heterosexual men seem to be unfamiliar with alternative paths to parenthood (Patterson \& Riskind, 2010), and some still envisage parenting as a feminine role (Gato \& Fontaine, 2017; Pelka, 2009). Nevertheless, future research should further examine the genesis of these differences.

Age was negatively associated with the motivation of "knowing one's fertility," with younger men assigning more importance to this motivation. According to Thijssen et al. (2017), this association is expected because younger, childless men have not yet confirmed their fertility status. Furthermore, the men with a lower level of education also valued this motivation more, so future research should explore this association.

Considering the psychological characteristics of the participants, men with higher levels of Conscientiousness assigned more importance to learning their fertility status. People with high levels of conscientiousness may be more motivated to donate based on willingness to pass on their "good genes" (Thijssen et al., 2017), because this will confirm their purpose and usefulness to society and themselves. Similarly, men with higher levels of Conservative values also ascribed more importance to learning their fertility status. This is unsurprising if we consider that more conservative individuals tend to value social order and assign more importance to traditional institutions (Schwartz, 1992, 1994), such as heteronormative families where children generally have a genetic link with their parents.

People with high levels of empathic concern donate in various contexts, and they are compassionate toward others and seem to be oriented toward alleviating the suffering of others in need (Verhaert \& Van den Poel, 2011). This explains the positive association between empathic concern and the motivation to help others have a child, as was found in this study. Conversely, religious values were negatively correlated with this motivation. Even though modern Portugal is a secular country, Catholic values still exert a certain influence (Dix, 2010). In our study, the negative association between adherence to religious values and helping someone to have a child may derive from the fact that Catholicism tends to reject alternative family configurations, including the pursuit of pregnancy through MAR (Rubio, 2015).

\section{Attitudes Toward Anonymity}

Willingness to be contacted by the child was the leastindicated attitude, differing from the assertions "parents 
Table 3 Correlations between motivations to donate, attitudes toward anonymity, attitudes towards donating for specific groups and sociodemographic variables and psychological variables

\begin{tabular}{|c|c|c|c|c|c|c|c|c|}
\hline & Age & Education level & Monthly income & $\begin{array}{l}\text { Conscientious- } \\
\text { ness }\end{array}$ & $\begin{array}{l}\text { Openness } \\
\text { to experi- } \\
\text { ence }\end{array}$ & $\begin{array}{l}\text { Empathic con- } \\
\text { cern }\end{array}$ & $\begin{array}{l}\text { Con- } \\
\text { servative } \\
\text { values }\end{array}$ & $\frac{\text { Religious values }}{}$ \\
\hline \multicolumn{9}{|c|}{ Motivations to donate } \\
\hline $\begin{array}{l}\text { Financial } \\
\text { compensa- } \\
\text { tion }\end{array}$ & -0.08 & -0.01 & $-0.12^{*}$ & 0.08 & 0.06 & 0.03 & $0.12 *$ & 0.02 \\
\hline $\begin{array}{l}\text { Knowing } \\
\text { one's fertil- } \\
\text { ity }\end{array}$ & $-0.15^{*}$ & $-0.21^{* *}$ & -0.04 & $0.14^{*}$ & -0.02 & 0.08 & $0.15^{* *}$ & 0.11 \\
\hline $\begin{array}{l}\text { Helping } \\
\text { someone to } \\
\text { have a child }\end{array}$ & 0.02 & -0.09 & -0.07 & 0.11 & 0.10 & $0.19 * *$ & -0.01 & $-0.14^{*}$ \\
\hline \multicolumn{9}{|l|}{$\begin{array}{l}\text { Attitudes towards } \\
\text { anonymity }\end{array}$} \\
\hline $\begin{array}{l}\text { Parents } \\
\text { should } \\
\text { disclose DI } \\
\text { conception } \\
\text { with the } \\
\text { child }\end{array}$ & $-0.15^{*}$ & -0.08 & -0.03 & 0.07 & 0.08 & 0.09 & 0.10 & 0.06 \\
\hline $\begin{array}{l}\text { The institu- } \\
\text { tion where } \\
\text { DI was } \\
\text { performed } \\
\text { can provide } \\
\text { information } \\
\text { about me to } \\
\text { the child, } \\
\text { since that } \\
\text { information } \\
\text { does not } \\
\text { identify me }\end{array}$ & -0.12 & -0.01 & -0.00 & 0.03 & 0.05 & 0.08 & 0.07 & -0.05 \\
\hline $\begin{array}{l}\text { I would be } \\
\text { will- } \\
\text { ing to be } \\
\text { contacted } \\
\text { by the child } \\
\text { when they } \\
\text { reached } \\
\text { majority } \\
\text { (18 years } \\
\text { old) }\end{array}$ & -0.09 & -0.11 & 0.04 & 0.08 & 0.10 & 0.10 & 0.06 & 0.05 \\
\hline \multicolumn{9}{|c|}{ Attitudes towards donating for specific groups } \\
\hline $\begin{array}{l}\text { Lesbian } \\
\text { woman } \\
\text { without } \\
\text { fertility } \\
\text { problems }\end{array}$ & -0.00 & 0.01 & -0.02 & 0.02 & 0.08 & $0.22 * *$ & -0.10 & $-0.31 * *$ \\
\hline $\begin{array}{l}\text { Different-sex } \\
\text { couple }\end{array}$ & -0.01 & 0.06 & 0.01 & 0.00 & 0.07 & $0.14^{*}$ & -0.09 & $-0.20^{* *}$ \\
\hline $\begin{array}{l}\text { Heterosexual } \\
\text { woman with } \\
\text { fertility } \\
\text { problems }\end{array}$ & -0.03 & -0.01 & -0.11 & 0.06 & 0.03 & 0.07 & -0.02 & $-0.21 * *$ \\
\hline $\begin{array}{l}\text { Lesbian } \\
\text { couple }\end{array}$ & -0.08 & -0.00 & -0.00 & -0.02 & 0.06 & $0.20 * *$ & -0.08 & $-0.28 * *$ \\
\hline
\end{tabular}


Table 3 (continued)

\begin{tabular}{cccccccc}
\hline & Age & Education level & Monthly income & $\begin{array}{l}\text { Conscientious- } \\
\text { ness }\end{array}$ & $\begin{array}{l}\text { Openness } \\
\text { to experi- } \\
\text { ence }\end{array}$ & $\begin{array}{l}\text { Empathic con- } \\
\text { cern }\end{array}$ & $\begin{array}{l}\text { Con- } \\
\text { servative } \\
\text { values }\end{array}$ \\
\hline $\begin{array}{c}\text { Heterosexual } \\
\text { woman } \\
\text { without }\end{array}$ & 0.09 & 0.04 & 0.04 & 0.08 & 0.07 & $0.13^{*}$ & -0.09 \\
$\begin{array}{l}\text { fertility } \\
\text { problems }\end{array}$ & & & & & & & $-0.29 * *$ \\
$\begin{array}{c}\text { Lesbian } \\
\text { woman } \\
\text { without } \\
\text { fertility } \\
\text { problems }\end{array}$ & -0.08 & 0.00 & -0.05 & -0.00 & 0.05 & $0.21^{* *}$ & -0.09 \\
\hline
\end{tabular}

${ }^{*} p<0.05, * * p<0.001$

should disclose DI conception with the child" and "the institution where DI was realized can provide information about me to the child, since that information does not identify me." This finding agrees with research that found that men tend to avoid donation if their identities may be disclosed (Bay et al., 2014; Thijssen et al., 2017). Nevertheless, a relatively positive view about non-anonymous donation was noticeable, because all participants endorsed disclosing DI conception to the child and releasing non-identifying information about the donor. No differences in attitudes toward anonymity were found as a function of sexual orientation, thus contradicting the study of Freeman et al. (2016), which verified that gay and bisexual men, when compared to their heterosexual peers, were more open minded when it came to anonymity and more willing to have contact with children conceived using their sperm. This study's results refuted our hypotheses about differences between heterosexual and non-heterosexual men for attitudes toward sperm donation.

For sociodemographic characteristics, age was negatively associated with the attitude that "parents should disclose DI conception to the child," with younger participants subscribing more to this attitude. According to Riggs and Russell (2011), men under the age of 26 preferred identity-release legislation, and this may reflect in the opinion that parents should disclose DI conception to the child. No psychological characteristics were associated with attitudes toward anonymity, perhaps due to the choice of psychological correlates in this study. Future research should therefore include other aspects, such as neuroticism and agreeableness.

\section{Attitudes Toward Donating for Specific Groups}

Regarding attitudes toward donating for specific groups, a positive tendency toward donating to all groups was discernible, and this is consistent with the findings of other studies (Bay et al., 2014; Ekerhovd et al., 2008; Thijssen et al., 2017). Nevertheless, donating to heterosexual women with fertility problems was the group regarded the most positively. This may come from the altruistic motivations to donate that participants reported. Indeed, altruism is based on a desire to help someone to have a child (Ekerhovd et al., 2008; Hedrih \& Hedrih, 2012; Thijssen et al., 2017; Van der Broeck et al., 2013), and infertile women may be perceived, a priori, as being at a greater disadvantage.

Empathic concern was positively associated with donating to most recipient groups. This likely derives from the fact that people with high levels of empathic concern tend to focus more on alleviating the suffering of others and showing compassion (Verhaert \& Van den Poel, 2011). In contrast, adherence to religious values was negatively associated with donating to all groups. As mentioned earlier, this may stem from the influence of Catholic views about family (Rubio, 2015).

\section{Limitations, Future Directions, and Implications for Practice}

Like any research endeavor, this study is not without limitations. More than half of our sample was highly educated, so it was not representative of the wider Portuguese population. Additionally, the imbalance in the number of heterosexual and non-heterosexual men may have further compromised the results and prevented us from drawing conclusions about the influence of this variable. The small magnitude of effects (except in the RM ANOVAs) also raised concerns and somewhat limited generalization of the findings.

Despite these limitations, however, our findings do have implications for practice. By shedding light on the motivations, attitudes, and characteristics of possible candidate donors, the findings of this study may inform future recruitment campaigns. Indeed, based on these 
findings, it could be argued that campaigns should target specific motivations, attitudes, and characteristics of potential donors. As Ferguson, Atsma, de Kort, and Veldhuizen (2012) reported in the context of blood donation, emphasizing the positive feelings that are associated with donation can increase donation rates, so a similar concept could be applied in the context of sperm donation. For example, in this study, the most frequently reported motivation to donate was to help someone have a child, which is an altruistic motivation. It may therefore be useful to highlight the altruistic nature of donation in any campaign.

This study also contributes to the view that withdrawing donation anonymity, which took place in Portugal in 2018, may not necessarily affect the number of potential donors, thus reflecting the positive trend toward non-anonymity reported by other studies (Bay et al., 2014; Thijssen et al., 2017). However, given a pattern of disengagement when the disclosed information is too personal or when there is a chance of contact with the child, the issue of anonymity should be further debated and clarified. Future recruitment campaigns should therefore stress that upon release of anonymity, the donor bears no obligation or commitment to the child. Likewise, it is crucial to emphasize that parenthood is a universal right in order to encourage sperm donation for any person or couple, regardless of fertility status or sexual orientation.

\section{Conclusion}

The present work contributes to the emergent research field of gamete donation by investigating motivations to donate, attitudes toward anonymity, and attitudes toward donating for specific groups, all from the perspective of potential donors. Motivations and attitudes were found to differ, but they did not differ as a function of sexual orientation. Groups with fertility issues were found to be slightly more favored than other recipients. The results of this study may be helpful in designing campaigns that are more effective at attracting male donors.

Authors' Contributions All authors contributed to the study conception and design. Material preparation, data collection, and analysis were performed by João Areias, Jorge Gato, and Mariana Moura Ramos. The first draft of the manuscript was written by João Areias, and all authors commented on previous versions of the manuscript. All authors read and approved the final manuscript.

\section{Compliance with Ethical Standard}

Conflict of Interest The authors declare that they have no conflicts of interest.

\section{References}

Acórdão $n^{\circ}$ 225/2018 de 24 de abril de 2018 do Tribunal Constitucional. Plenário. Relator: Conselheiro Pedro Machete. Retrieved from: www.tribunalconstitucional.pt/tc/acordaos/20180225.html

Almeling, R. (2006). 'Why do you want to be a donor?': gender and the production of altruism in egg and sperm donation. New Genetics \& Society, 25(2), 143-157. https://doi.org/10.1080/14636770600855184.

Batson, C. D. (1987). Prosocial motivation: Is it ever truly altruistic? In L. Berkowitz (Ed.), Advances in experimental social psychology, Vol. 20 (p. 65-122). Academic Press. doi:https://doi.org/10.1016/ S0065-2601(08)60412-8

Bay, B., Larsen, P. B., Kesmodel, U. S., \& Ingerslev, H. J. (2014). Danish sperm donors across three decades: motivations and attitudes. Fertility \& Sterility, 101(1), 252-257.e251. https://doi.org/10.1016/j. fertnstert.2013.09.013.

Bolt, S., Eisinga, R., Venbrux, E., Kuks, J. B., \& Gerrits, P. O. (2011). Personality and motivation for body donation. Annals of AnatomyAnatomischer Anzeiger, 193(2), 112-117. https://doi.org/10.1016/j. aanat.2011.01.005.

Crawford, I., \& Solliday, E. (1996). The attitudes of undergraduate college students toward gay parenting. Journal of Homosexuality, 30(4), 63-77. https://doi.org/10.1300/J082v30n04_04.

Cohen, E. L., \& Hoffner, C. (2013). Gifts of giving: The role of empathy and perceived benefits to others and self in young adults' decisions to become organ donors. Journal of Health Psychology, 18(1), 128-138. https://doi.org/10.1177/1359105311433910.

Costa, P. T., \& McCrae, R. R. (1992). Normal personality assessment in clinical practice: The NEO Personality Inventory. Psychological assessment, 4(1), 5.

Davis, M. H. (1983). Measuring individual differences in empathy: Evidence for a multidimensional approach. Journal of Personality and Social Psychology, 44, 113-126.

Decety, J., \& Jackson, P. L. (2004). The functional architecture of human empathy. Behavioral and Cognitive Neuroscience Reviews, $3,71-100$.

Dix, S. (2010). As esferas seculares e religiosas na sociedade portuguesa [The secular and the religious spheres in Portuguese Society]. Análise Social, 45, 5-27.

Ekerhovd, E., Faurskov, A., \& Werner, C. (2008). Swedish sperm donors are driven by altruism, but shortage of sperm donors leads to reproductive travelling. Upsala Journal of Medical Sciences, 113(3), 305-313. https://doi.org/10.3109/2000-1967-241.

Faul, F., Erdfelder, E., Lang, A.-G., \& Buchner, A. (2007). G*Power 3: A flexible statistical power analysis program for the social, behavioral, and biomedical sciences. Behavior Research Methods, 39, 175-191.

Ferguson, E., Atsma, F., de Kort, W., \& Veldhuizen, I. (2012). Exploring the pattern of blood donor beliefs in first-time, novice, and experienced donors: Differentiating reluctant altruism, pure altruism, impure altruism, and warm glow. Transfusion, 52, 343355. https://doi.org/10.1111/j.1537-2995.2011.03279.x.

Freeman, T., Jadva, V., Tranfield, E., \& Golombok, S. (2016). Online sperm donation: a survey of the demographic characteristics, motivations, preferences and experiences of sperm donors on a connection website. Human Reproduction, 31(9), 2082-2089. https://doi.org/10.1093/humrep/dew166.

Fortescue, E. (2003). Gamete donation - where is the evidence that there are benefits in removing the anonymity of donors? A patients viewpoint. Reproductive BioMedicine Online (Reproductive Healthcare Limited), 7(2), 139-144. https://doi.org/10.1016/ S1472-6483(10)61743-9.

Gato, J., \& Fontaine, A. M. (2013). Anticipation of the sexual and gender development of children adopted by same-sex couples. International Journal of Psychology, 48(3), 244-253. https://doi. org/10.1080/00207594.2011.645484. 
Gato, J., \& Fontaine, A. M. (2016). Attitudes toward adoption by samesex couples: Effects of gender of the participant, sexual orientation of the couple, and gender of the child. Journal of GLBT Family Studies, 12(1), 46-67. https://doi.org/10.1080/1550428X.2015.1049771.

Gato, J., \& Fontaine, A. (2017). Predicting attitudes toward lesbian and gay parent families among portuguese students from helping professions. International Journal of Sexual Health, 29(2), 187201. https://doi.org/10.1080/19317611.2016.1268232.

Gato, J., Leal, D., Coimbra, S., \& Tasker, F. (2020). Anticipating parenthood among lesbian, gay, bisexual, and heterosexual young adults without children in Portugal: Predictors and profiles. Frontiers in Psychology, 11. doi:https://doi.org/10.3389/fpsyg. 2020.01058

Golombok, S. (2015). Donor conception families. In S. Golombok, Modern families. Parents and children in new family forms (pp. 91-116).Cambridge: Cambridge University Press.

Granjo, M., \& Peixoto, F. (2013). Contributo para o estudo da Escala de Valores Humanos de Schwartz em professores. Laboratório de Psicologia, 11(1), 3-17.

Hedrih, A., \& Hedrih, V. (2012). Attitudes and motives of potential sperm donors in Serbia. Stavovi i motivi potencijalnih davalaca sperme u Srbiji., 69(1), 49-57. https://doi.org/10.2298/VSP1201049H.

Kalampalikis, N., Haas, V., Fieulaine, N., Doumergue, M., \& Deschamps, G. (2013). Giving or giving back: New psychosocial insights from sperm donors in France. Psychology, Health \& Medicine, 18(1), 1-9. https://doi.org/10.1080/13548506.2012.668195.

Kline, R. B. (2011). Methodology in the Social Sciences. Principles and practice of structural equation modeling (3rd ed.). New York: Guilford Press

Limpo, T., Alves, R. A., \& Catro, S. L. (2010). Medir a empatia: Adaptação portuguesa do Índice de Reactividade Interpessoal. Laboratório de Psicologia, 8(2), 171-184.

Magalhães, E., Salgueira, A., Gonzalez, A. J., Costa, J. J., Costa, M. J., Costa, P., \& Lima, M. P. D. (2014). NEO-FFI: Psychometric properties of a short personality inventory in Portuguese context. Psicologia: Reflexão e Crítica, 27(4), 642-657.

Macpherson, I. (2019). Ethical reflections about the anonymity in gamete donation. Human Reproduction, 34(9), 1847-1848. https:// doi.org/10.1093/humrep/dez142.

McCrae, R. R., \& Costa, P. T., Jr. (1997). Conceptions and correlates of openness to experience. In R. Hogan, J. A. Johnson, \& S. R. Briggs (Eds.), Handbook of personality psychology (pp. 825847). San Diego, CA: Academic Press.

McCrae, R. R., \& Costa, P. T., Jr. (2008). Empirical and theoretical status of the five-factor model of personality traits. In G. Boyle, G. Matthews, \& D. Saklofske (Eds.), Sage Handbook of personality theory and assessment (Vol. 1, pp. 273-294). Los Angeles: Sage.

Patterson, C. J., \& Riskind, R. G. (2010). To be a parent: Issues in family formation among gay and lesbian adults. Journal of GLBT Family Studies, 6(3), 326-340. https://doi.org/10.1080/1550428X. 2010.490902.

Pelka, S. (2009). Sharing motherhood: Maternal jealousy among lesbian co-mothers. Journal of Homosexuality, 56(2), 195-217. https://doi.org/10.1080/00918360802623164.

Pennings, G. (2019a). Genetic databases and the future of donor anonymity. Human Reproduction, 34(5), 786-790. https://doi. org/10.1093/humrep/dez029.
Pennings, G. (2019b). Reply: Ethics of anonymity in gamete donation and genetic databases. Human Reproduction, 34(9), 1850-1851. https://doi.org/10.1093/humrep/dez145.

Ravitsky, V. (2017). The right to know one's genetic origins and cross-border medically assisted reproduction. Israel Journal of Health Policy Research, 6(1), 3. https://doi.org/10.1186/s13584016-0125-0.

Riggs, D. W., \& Russell, L. (2011). Characteristics of men willing to act as sperm donors in the context of identity-release legislation. Human reproduction, 26(1), 266-272. https://doi.org/10.1093/humrep/ deq314.

Rubio, J. H. (2015). Family ties: A Catholic response to donorconceived families. Christian Bioethics, 21(2), 181-198. https:// doi.org/10.1093/cb/cbv003.

Ryckman, R. M., Gold, J. A., Reubsaet, A., \& van den Borne, B. (2009). Value priorities and intention to register for posthumous organ donation in Dutch adolescents. The Journal of Social Psychology, 149(2), 213-227. https://doi.org/10.3200/SOCP.149.2.213-228.

Schwartz, S. H. (1992). Universals in the content and structure of values: Theoretical advances and empirical tests in 20 countries. In M. P. Zanna (Ed.), Advances in Experimental Social Psychology (Vol. 25, pp. 1-65). Orlando: Academic Press.

Schwartz, S.H. (1994). Beyond individualism/collectivism: New dimensions of values. In U. Kim, H.C. Triandis, C. Kagitcibasi, S.C. Choi e G. Yoon (Eds.), Individualism and collectivism: Theory application and methods. Newbury Park, CA: Sage.

Thijssen, A., Provoost, V., Vandormael, E., Dhont, N., Pennings, G., \& Ombelet, W. (2017). Motivations and attitudes of candidate sperm donors in Belgium. Fertility \& Sterility, 108(3), 539-547. https:// doi.org/10.1016/j.fertnstert.2017.06.014.

Thorn, P., Katzorke, T., \& Daniels, K. (2008). Semen donors in Germany: A study exploring motivations and attitudes. Human Reproduction, 23(11), 2415-2415. https://doi.org/10.1093/ humrep/den279.

Van der Broeck, U., Vandermeeren, M., Vanderschueren, D., Enzlin, P., Demyttenaere, K., \& D'Hooghe, T. (2013). A systematic review of sperm donors: demographic characteristics, attitudes, motives and experiences of the process of sperm donation. Human Reproduction Update, 19(1), 37-51. https://doi.org/10.1093/ humupd/dms039.

Verhaert, G. A., \& Van den Poel, D. (2011). Empathy as added value in predicting donation behavior. Journal of Business Research, 64(12), 1288-1295. https://doi.org/10.1016/j.jbusres.2010.12.024.

White, K. M., Poulsen, B. E., \& Hyde, M. K. (2017). Identity and personality influences on donating money, time, and blood. Nonprofit and Voluntary Sector Quarterly, 46(2), 372-394. https:// doi.org/10.1177/0899764016654280.

Zegers-Hochschild, F., Adamson, G. D., Dyer, S., Racowsky, C., de Mouzon, J., Sokol, R., et al. (2017). The International Glossary on Infertility and Fertility Care, $2017 \uparrow \$ \S$. Human Reproduction, 32(9), 1786-1801. https://doi.org/10.1093/humrep/dex234.

Publisher's Note Springer Nature remains neutral with regard to jurisdictional claims in published maps and institutional affiliations. 